\title{
PERAN KOMUNIKASI DALAM KELUARGA TERHADAP PERILAKU MENYIMPANG ANAK DAN REMAJA ( SYSTEMATIC REVIEW)
}

\author{
Genta Sakti ${ }^{1}$ Neila Sulung ${ }^{2}$ \\ Email: gentasakti64@gmail.com/Email: neilasulung_64@yahoo.com \\ Institut Agama Islam Negeri Bukittinggi /Universitas Fort De Kock Bukittinggi
}

Submitted: 14-04-2020, Reviewer: 18-04-2020, Accepted: 27-04-2020

ABSTRAK

Latar belakang: Dikalangan remaja sering dijumpai adanya perilaku yang menyimpang. Perilaku menyimpang merupakan hasil dari proses sosialisasi yang tidak sempurna. Kelompok yang paling rentan dalam proses perilaku menyimpang yaitu para remaja. Hal ini dapat ditanggulangi apabila fungsi keluarga berjalan dengan baik, karena Keluarga merupakan fungsi sosialisasi bagi anggota keluarga terutama anak, karena pertama kali anak dilahirkan adalah di dalam keluarga yang merupakan lembaga pertama dan utama. Tujuan penulisan artikel ini adalah untuk mereveiw beberapa tulisan yang berhubungan dengan komunikasi keluarga terhadap penyimpangan perilaku pada anak dan remaja, Metodelogi Review yang dilakukan melakukan review artikel sebanyak 53 artikel yang diseleksi sesuai kata kunci, yang menjadi sampel dalam penulisan ini adalah 26 tulisan 12 artikel internasional dan 14 artikel nasional. Jenis penelitian baik kuantitatif maupun kualitatif, Hasil Penelusuran : Dari 26 artikel yang dibaca yang menyebabkan terjadinya perilaku yang menyimpang pada anak dan remaja disebabkan 1. komunikasi atau peran keluarga/ orang tua karena lingkungan pertama dan utama yang dapat mengarahkan seorang anak untuk menghadapi kehidupannya adalah keluarga. 2. Lingkungan sekolah membentuk karakter lebih kurang 8 jam anak berada dengan guru yang menjadi orang yang dipercaya. 3. Lingkungan teman sebaya yang membawa dan mengajak kearah positif maupun negatif. Kesimpulan: Lingkungan rumah tangga, sekolah dan teman sebaya perlu mendapat perhatian khusus dalam mencengah terjadi penyimpangan perilaku yang tidak kita inginkan.

Kata kunci: Komunikasi, keluarga, perilaku, anak dan remaja

\section{A. Pendahuluan}

Indonesia telah meratifikasi Konvensi Hak-Hak Anak melalui Keputusan Presiden No 36 Tahun 1990. KHA terdiri dari delapan Klaster (Kelompok). Salah satu Klaster yaitu klaster VII mengatur tentang hak anak atas pendidikan dan perlindungan anak dalam proses pendidikan yang harus dilakukan oleh negara. KHA Klaster VII terdiri dari Pasal 28 tentang hak pendidikan anak, Pasal 29 tentang tujuan pendidikan dan Pasal 31 tentang waktu luang, rekreasi dan kegiatan budaya, yang jika dilaksanakan dengan baik maka mengembangkan potensi anak menjadi kapasitas semaksimal mungkin dan memiliki kepribadian yang kuat (KEMENTERIAN \& INDONESIA, 2019), Lingkungan pertama dan utama yang dapat mengarahkan seorang anak untuk menghadapi kehidupannya adalah keluarga. Melalui keluarga, anak dibimbing untuk mengembangkan kemampuan dan kreativitasnya serta menyimak nilai-nilai sosial yang berlaku. Keluarga perlu memperkenalkan anak 
kepada lingkungan yang lebih luas, dan di tangan keluargalah anak dipersiapkan untuk menghadapi masa depannya dengan segala kemungkinan yang timbul, (A. Sari, Hubeis, Mangkuprawira, \& Saleh, 2010)

Komunikasi antar pribadi merupakan suatu proses interaksi dan pembagian makna yang terkandung dalam gagasan- gagasan maupun perasaan. Komunikasi antarpribadi yang dilakukan dalam keluarga bertujuan untuk mempererat hubungan sosial di antara individu yang ada dalam keluarga. Masa remaja merupakan masa yang ditandai perubahan-perubahan yang sangat cepat dan berarti. Perubahan - perubahan terjadi dalam segi fisiologis, emosional, sosial dan intelektual. (Farin Nur \& Program, 2020). Untuk pembentukan perilaku seorang anak ditengah keluarga sangat penting sesuai dengan pendapat, (KEMENTERIAN \& INDONESIA, 2019) Mengajarkan anak dalam menghormati perbedaan pandangan. Ketika anak berbeda pandangan dengan orang tua, dan orang tua senantiasa mengajarkan berbeda pandangan dengan argumentasi yang jelas serta anak diluruskan dengan sopan, lembut dan bijak (SLB), maka terbentuk pada jiwa anak sikap dan perilaku positif, yakni siap beda pandangan dengan siapapun dengan penuh rasa hormat hingga remaja, dewasa. Tidak akan terjadi perilaku sosial menyimpang anak merupakan masalah dunia, tak satu negara pun yang terbebas dari masalah ini. Berkaitan dengan permasalahan pada anak usia remaja, fenomena yang sekarang banyak terjadi, dan sering kita lihat di media massa maupun eletronik serta media sosial. tindakan kejahatan, perilaku seks, narkoba, tawuran, kebiasaan merokok dan sebagainya merupakan contoh nyata dari tindakan negatif anak usia remaja saat ini. Penyimpangan seksual yang terjadi sangat dibutuh peran orang tua seperti penelitian, (Schouten, Putte, Pasmans, \& Meeuwesen, 2007). Berkaitan dengan permasalahan pada anak usia remaja, fenomena yang sekarang banyak terjadi, dan sering kita lihat di media massa maupun eletronik serta media sosial. tindakan kejahatan, perilaku seks, narkoba, tawuran, kebiasaan merokok dan sebagainya merupakan contoh nyata dari tindakan negatif anak usia remaja saat ini.(Sondakh \& Kalesaran, 2017).

Pada masa sekarang masalah ketidaksiapan orang tua dalam membina anak-anak sering dianggap sebagai pemicu terjadinya masalah-masalah sosial dan kenakalan remaja, karena orang tua dinilai kurang mampu memberi perhatian khusus kepada anak. Interaksi dan komunikasi dalam keluarga (orang tua anak) kurang tercipta secara dinamis. Oleh karena itu, orang tua perlu menanamkan pendidikan kepada anak sejak dari dini agar anak mampu memahami hakikat kehidupan yang sesuai menurut ajaran agama. (Tangkudung, 2014). Untuk mengatasi masalah diatas perlu adanya mediasi dari orang tua dan guru dalam mengatasi perilaku mengimpang dan tekanan social sesuai dengan penelitian, (Press, 2006). Keluarga merupakan tempat di mana proses interaksi sosial primer berlangsung dan menjadi tempat ditanamkannya pendidikan moral dan agama. Sehingga keluarga terutama orangtua harus ikut bertanggung jawab dalam membimbing anaknya. (ILMU KOMUNIKASI DAN ISLAM, 2008). Kondisi ini didukung oleh penelitian yang 
dilakukan (Farin Nur \& Program, 2020), Kesalahan orangtua atau keluarga dalam merespons sikap remaja terkadang mengarah kepada pengekangan. Selain penjagaan diri remaja, pendidikan moral pun dibutuhkan, namun pendidikan moral ini harus dilakukan justru tidak pada saat mereka menginjak masa remaja, namun pendidikan ini harus dilakukan semenjak dini.

Berdasarkan dan permasalah yang ada diatas penelitian melakukan beberapa kajian dari beberapa jurnal serta artikel yang berkaitan dengan komunikasi peran keluarga orang tua serta guru terjadinya perilaku yang menyimpang pada anak dan dan remaja.

\section{B. Metodologi Penelitian}

Penggunaan metode pada penelitian ini adalah Studi literature review, yaitu suatu studi yang dilakukan untuk menganalisis dari literatur-literatur yang dipilih dari beberapa sumber sehingga menjadi kesimpulan dan menjadi ide baru. Jurnal yang digunakan dalam studi ini adalah jurnal-jurnal yang membahas mengenai topik dengan kata kunci yaitu : Peran keluarga, orang, anak remaja dan perilaku yang menyimpang. Penulisan sebanyak 53 tulisan artikel, setelah dilakukan seleksi sesuai kata kunci yang dianalisis 26 artikel, yang terdiri dari 12 artikel internasional dan 14 artikel Nasional dengan desain penelitian kuantitatif dan kualitatif, pada priode 2015 -2019 ( tahun terakhir ) 


\section{ANALISIS JURNAL INTERNASIONAL DAN NASIONAL 2015 -2019}

\begin{tabular}{|c|c|c|c|c|c|}
\hline No & $\begin{array}{l}\text { Nama } \\
\text { Jurnal/Penulis/T } \\
\text { ahun }\end{array}$ & Judul Pelt & Tujuan Pelt & Metoda & Hasil Pelt \\
\hline 1 & $\begin{array}{l}\text { Journal of } \\
\text { Adolescent } \\
\text { Health/ (Rogers } \\
\text { et al., 2015) }\end{array}$ & $\begin{array}{l}\text { Quality of } \\
\text { ParenteAdolescen } \\
\mathrm{t} \text { Conversations } \\
\text { About Sex and } \\
\text { Adolescent Sexual } \\
\text { Behavior: An } \\
\text { Observational } \\
\text { Study }\end{array}$ & $\begin{array}{l}\text { Studies suggest that } \\
\text { the quality } \\
\text { ofparenteadolescent } \\
\text { communication } \\
\text { about sex uniquely } \\
\text { predicts adolescent } \\
\text { sexual behavior. }\end{array}$ & $\begin{array}{ll}\text { logistic } & \text { regression } \\
\text { analyses } & \end{array}$ & $\begin{array}{l}\text { Kualitas komunikasi sangat penentukan perilaku } \\
\text { anak remaja tentang seksual. Komunikasi yang baik } \\
\text { dari orang tua dapat mencengah perilaku yang } \\
\text { menyimpang pada anak remaja }\end{array}$ \\
\hline 2 & $\begin{array}{l}\text { Jurnal Psikologi } \\
\text { Tabularasa. } \\
\text { (Suhartati, } \\
\text { Hendrati, } \\
\text { Psikologi, \& } \\
\text { Malang, 2015) }\end{array}$ & $\begin{array}{l}\text { Perbedaan } \\
\text { Komunikasi } \\
\text { Interpersonal } \\
\text { Anak- } \\
\text { Orangtua Ditinjau } \\
\text { Dari } \\
\text { Keharmonisan } \\
\text { Perkawinan Orang } \\
\text { Tua }\end{array}$ & $\begin{array}{l}\text { mengetahui } \\
\text { perbedaan } \\
\text { komunikasi } \\
\text { interpersonal anak- } \\
\text { orang tua ditinjau } \\
\text { dari keharmonisan } \\
\text { perkawinan orang } \\
\text { tua. }\end{array}$ & $\begin{array}{l}\text { Uji Asumsi yang } \\
\text { digunakan } \\
\text { dalam penelitian ini } \\
\text { adalah uji normalitas dan } \\
\text { uji homogenitas. Hasil }\end{array}$ & $\begin{array}{l}\text { Keluarga harmonis akan menghasilkan perilaku- } \\
\text { perilaku yang positif, anak memiliki sopan santun } \\
\text { yang baik terhadap orang tua maupun lingkungan, } \\
\text { anak menjadi berani mengungkapkan apa yang } \\
\text { dialami dalam kehidupan dan berani untuk terbuka } \\
\text { dalam segala hal kepada orang tua, anak memiliki } \\
\text { kepercayaan diri yang baik karena orang tua dapat } \\
\text { menjadi figur dan contoh bagi anak-anak. }\end{array}$ \\
\hline 3 & $\begin{array}{l}\text { Jurnal Imu } \\
\text { Komunikasi, } \\
\text { (Zuhri, 2015) }\end{array}$ & $\begin{array}{lr}\text { Pola } & \text { Komunikasi } \\
\text { Orang } & \text { Tua } \\
\text { Dengan } & \text { Anak } \\
\text { Pada Kasus } & \text { Seks } \\
\text { Pranikah } & \end{array}$ & $\begin{array}{l}\text { Tujuan dari } \\
\text { penelitian ini adalah } \\
\text { untuk mengetahui } \\
\text { pola komunikasi } \\
\text { orang tua dan anak } \\
\text { pada kasus seks } \\
\text { pranikah }\end{array}$ & 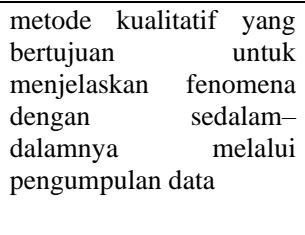 & $\begin{array}{l}\text { Informan menunjukkan bahwa remaja yang pernah } \\
\text { melakukan hubungan seks pranikah ditemukan dua } \\
\text { keluarga menganut pola komunikasi permissive } \\
\text { (bebas) }\end{array}$ \\
\hline 4 & $\begin{array}{l}\text { Jurnal } \\
\text { Komunikasi } \\
\text { KAREBA(Yuni } \\
\text { artanty Ashary, } \\
\text { Tawany }\end{array}$ & $\begin{array}{l}\text { Pengendalian } \\
\text { Perilaku } \\
\text { Emosional Anak } \\
\text { Tk } \\
\text { Melalui } \\
\text { Komunikasi }\end{array}$ & $\begin{array}{l}\text { Penelitian ini } \\
\text { bertujuan untuk (a) } \\
\text { mengetahui } \\
\text { gambaran perilaku } \\
\text { emosional anak TK } \\
\text { di } \quad \text { Kec. }\end{array}$ & $\begin{array}{l}\text { Penelitian ini merupakan } \\
\text { eks-post-fakto yang } \\
\text { kuantitatif. }\end{array}$ & $\begin{array}{l}\text { Semakin berkurang (terkendali) perilaku emosional } \\
\text { anak. Sekitar } 32,8 \% \text { pengendalian perilaku } \\
\text { emosional anak disebabkan oleh faktor intensitas } \\
\text { komunikasi antara guru dengan orang tua dalam } \\
\text { membicarakan permasalahan perilaku emosional } \\
\text { anak }\end{array}$ \\
\hline
\end{tabular}




\begin{tabular}{|c|c|c|c|c|c|}
\hline & $\begin{array}{l}\text { Rahamma, } \\
\text { 2015) }\end{array}$ & $\begin{array}{l}\text { Antara Guru } \\
\text { Dengan Orang } \\
\text { Tua Di Kec. } \\
\text { Biringkanaya } \\
\text { Kota Makassar }\end{array}$ & 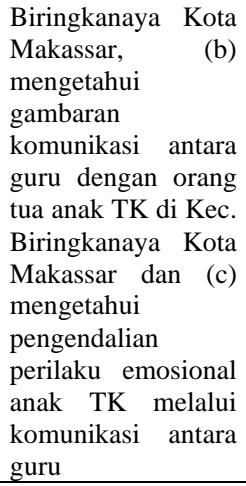 & & \\
\hline 5 & $\begin{array}{l}\text { Jurnal Edueksos } \\
\text { (Komunikasi \& } \\
\text { Keluarga, 2015) }\end{array}$ & $\begin{array}{l}\text { Pembentukan } \\
\text { Sikap Sosial } \\
\text { Melalui } \\
\text { Komunikasi } \\
\text { Dalam Keluarga }\end{array}$ & $\begin{array}{lr}\text { Peran } & \text { keluarga } \\
\text { dalam } & \text { membentuk } \\
\text { sikap } & \text { social anak } \\
\text { remaja } & \end{array}$ & Penelitian kualitatif & $\begin{array}{l}\text { Manfaat iklim komunikasi yang positif, sikap anak } \\
\text { yang positif akan tumbuh dan berkembang. Seorang } \\
\text { anak akan memiliki kepercayaan diri yang kuat, } \\
\text { mandiri, santun, menghormati sesama, tolong } \\
\text { menolong, disiplin dan sifat-sifat positif lainnya. } \\
\text { Dengan membangun komunikasi yang intensif } \\
\text { dalam keluarga diharapkan sikap sosial anak remaja } \\
\text { akan jauh lebih baik. }\end{array}$ \\
\hline 6 & $\begin{array}{l}\text { Jurnal E-?- } \\
\text { Komunikasi(Pet } \\
\text { ra, Devi, } \\
\text { Komunikasi, } \\
\text { Kristen, \& } \\
\text { Surabaya, 2015) }\end{array}$ & $\begin{array}{l}\text { Proses } \\
\text { Komunikasi } \\
\text { Interpersonal Ibu } \\
\text { Yang Bekerja } \\
\text { Dalam } \\
\text { Pembentukkan } \\
\text { Sikap Konatif } \\
\text { Anak }\end{array}$ & $\begin{array}{l}\text { Mengetahui } \\
\text { bagaimana proses } \\
\text { komunikasi } \\
\text { interpersonal } \\
\text { ibu yang bekerja } \\
\text { dalam pembentukan } \\
\text { sikap konatif anak. }\end{array}$ & $\begin{array}{l}\text { studi kasus single case } \\
\text { dengan teknik } \text { analisis } \\
\text { data } \quad \text { Miles } r \text { dan } \\
\text { Huberman. Hasil }\end{array}$ & $\begin{array}{l}\text { Komunikasi interpersonal didalam keluarga, } \\
\text { dibutuhkan adanya saling memahami keadaan lawan } \\
\text { bicara masing-masing. Dalam konteks ini adalah ibu } \\
\text { yang bekerja. Sebagai seorang wanita yang sudah } \\
\text { berkeluarga, meskipun bekerja, tetap saja tidak boleh } \\
\text { lupa dengan kodrat nya sebagai ibu rumah tangga. } \\
\text { Sebagai ibu yang bekerja, sudah selayaknya ibu } \\
\text { berusaha untuk mempunyai management waktu } \\
\text { yang baik, agar dapat membagi waktu antara bekerja } \\
\text { dan mengurus rumah tangga }\end{array}$ \\
\hline 7 & $\begin{array}{l}\text { Journal of } \\
\text { Adolescent } \\
\text { Health, (Ford et } \\
\text { al., 2016) }\end{array}$ & $\begin{array}{l}\text { Parent and } \\
\text { Adolescent } \\
\text { Interest } \\
\text { Receiving } \\
\text { Adolescent Health } \\
\text { Communication } \\
\end{array}$ & \begin{tabular}{lr}
\multicolumn{2}{l}{ Patient-centered } \\
health & care \\
recognizes & that \\
adolescents & and \\
parents & are \\
stakeholders & in \\
\end{tabular} & 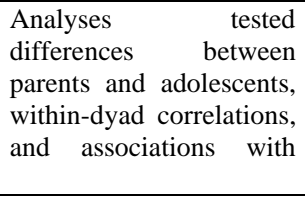 & $\begin{array}{l}\text { Intervensi perawatan primer yang layak yang secara } \\
\text { efektif meningkatkan komunikasi kesehatan orang } \\
\text { tua-remaja dan hasil kesehatan remaja spesifik } \\
\text { diperlukan. }\end{array}$ \\
\hline
\end{tabular}




\begin{tabular}{|c|c|c|c|c|c|}
\hline & & \begin{tabular}{lr|} 
Information & From \\
Primary & Care \\
Clinicians &
\end{tabular} & $\begin{array}{l}\text { adolescent health. } \\
\text { We investigate } \\
\text { adolescent and } \\
\text { parent interest in } \\
\text { receiving } \\
\text { information about } \\
\text { health topics and } \\
\text { parent-teen } \\
\text { communication } \\
\text { from clinicians } \\
\end{array}$ & $\begin{array}{l}\text { adolescent gender and } \\
\text { age. }\end{array}$ & \\
\hline 8 & $\begin{array}{l}\text { Procedia - Social } \\
\text { and Behavioral } \\
\text { Sciences(Berdib } \\
\text { ayeva, Garber, } \\
\text { \& Ivanov, 2016) }\end{array}$ & $\begin{array}{l}\text { Psychological } \\
\text { prevention of } \\
\text { older adolescents' } \\
\text { interpersonal } \\
\text { relationships, who } \\
\text { are prone to } \\
\text { internet addiction }\end{array}$ & $\begin{array}{l}\text { This article deals } \\
\text { with the nature of } \\
\text { the relationship of } \\
\text { interpersonal } \\
\text { relations and } \\
\text { Internet addiction. } \\
\text { The influence of } \\
\text { deviant behavior on } \\
\text { the interpersonal } \\
\text { relationships of } \\
\text { older adolescents is } \\
\text { shown }\end{array}$ & $\begin{array}{l}\begin{array}{l}\text { Diagnosis of } \\
\text { psychological } \\
\text { characteristics }\end{array} \\
\text { interpersonal of } \\
\text { relationships of older } \\
\text { adolescents who are } \\
\text { prone to Internet } \\
\text { addiction }\end{array}$ & $\begin{array}{l}\text { Hasil penelitian menunjukkan bahwa penurunan } \\
\text { jumlah remaja yang lebih tua, ditandai dengan } \\
\text { kecenderungan kecanduan internet, diamati setelah } \\
\text { melakukan pemeliharaan preventif. }\end{array}$ \\
\hline 9 & $\begin{array}{l}\text { Jurnal } \\
\text { Komunikasi, } \\
\text { (Firdanianty } \\
\& \quad \text { Herien } \\
\text { Puspitawati, } \\
\text { 2016) }\end{array}$ & \begin{tabular}{lr|} 
Pola Komunikasi \\
Remaja & Dan \\
Pengaruhnya & \\
Terhadap & \\
Kecerdasan & \\
Emosional & Siswa \\
Sma Di & Kota \\
Bogor &
\end{tabular} & \begin{tabular}{|l|} 
Menganalisis \\
pengaruh pola \\
komunikasi remaja \\
dengan keluarga, \\
sekolah, dan \\
teman sebaya \\
terhadap kecerdasan \\
emosional siswa \\
SMA di kota Bogor
\end{tabular} & 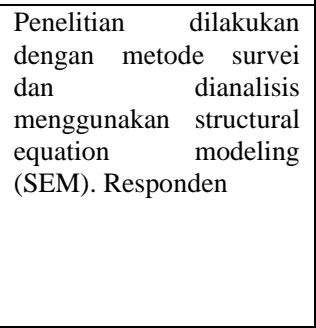 & $\begin{array}{l}\text { Hasil SEM menunjukkan ada pengaruh nyata antara } \\
\text { pola komunikasi remaja dengan keluarga, sekolah, } \\
\text { dan teman sebaya terhadap kecerdasan emosional. } \\
\text { Pola komunikasi remaja dengan teman sebaya } \\
\text { berkontribusi lebih besar terhadap kecerdasan } \\
\text { emosional dibandingkan pola komunikasi remaja } \\
\text { dengan keluarga atau sekolah. Penelitian ini juga } \\
\text { menemukan bahwa durasi pembicaraan } \\
\text { berkontribusi paling besar terhadap pola komunikasi } \\
\text { remaja dengan teman sebaya }\end{array}$ \\
\hline 10 & \begin{tabular}{|lr} 
Skripsi, & (Novi \\
Kartika & Sari, \\
$2016)$ & \\
\end{tabular} & $\begin{array}{l}\text { Hubungan Antara } \\
\text { Dukungan } \\
\text { Keluarga Dengan } \\
\text { Kecenderungan } \\
\text { Perilaku } \\
\text { Delinkuen Pada } \\
\text { Remaja } \\
\text { Publikasi }\end{array}$ & $\begin{array}{|lr|}\text { Penelitian ini } \\
\text { bertujuan untuk } \\
\text { mengetahui } \\
\text { hubungan antara } \\
\text { dukungan } \\
\text { keluarga,tingkat } \\
\text { dukungan, } \\
\text { sumbangan } & \text { efektif } \\
\end{array}$ & $\begin{array}{l}\text { Peneliti menggunakan } \\
\text { metode kuantitatif }\end{array}$ & $\begin{array}{l}\text { Berdasarkan hasil analisis diketahui variabel } \\
\text { kecenderungan perilaku delinkuen mempunyai } \\
\text { rerata empirik (RE) sebesar 81,71 dan rerata } \\
\text { hipotetik (RH) sebesar 112,5 yang berarti } \\
\text { kecenderungan perilaku delinkuen subjek penelitian } \\
\text { tergolong rendah. Variabel dukungan keluarga } \\
\text { mempunyai rerata empirik (RE) sebesar } 111,30 \text { dan } \\
\text { rerata hipotetik (RH) sebesar 90 yang berarti }\end{array}$ \\
\hline
\end{tabular}




\begin{tabular}{|c|c|c|c|c|c|}
\hline & & & $\begin{array}{l}\text { kel dengan } \\
\text { kecenderungan } \\
\text { perilaku delinkuen } \\
\text { pada remaja, }\end{array}$ & & $\begin{array}{l}\text { dukungan keluarga subjek penelitian tergolong } \\
\text { tinggi. }\end{array}$ \\
\hline 11 & $\begin{array}{l}\text { Jurnal } \\
\text { Cakrawala, } \\
\text { (Nurlita, 2016) }\end{array}$ & $\begin{array}{l}\text { Pola Komunikasi } \\
\text { Interpersonal } \\
\text { Dalam } \\
\text { Pemberdayaan } \\
\text { Perilaku Anak } \\
\text { Terhadap } \\
\text { Tayangan } \\
\text { Sinetron Di } \\
\text { Televisi } \\
\text { Interpersonal }\end{array}$ & $\begin{array}{l}\text { tujuan penelitian ini } \\
\text { adalah untuk } \\
\text { menganalisa suatu } \\
\text { pola komunikasi } \\
\text { interpersonal dalam } \\
\text { keluarga untuk } \\
\text { pemberdayaan } \\
\text { perilaku anak } \\
\text { sebagai } \\
\text { perlindungan anak } \\
\text { dalam menonton } \\
\text { tayangan sinetron di } \\
\text { televisi. }\end{array}$ & $\begin{array}{lr}\text { Pendekatan deskriptif } \\
\text { kualitatif dan analisa data } \\
\text { kuantitatif digunakan } \\
\text { untuk mendukung } \\
\text { pemecahan permasalahan } \\
\text { penelitian dalam } \\
\text { memahami subyek yang } \\
\text { diteliti. }\end{array}$ & $\begin{array}{l}\text { Hasil penelitian ini adalah pada ranah kognitif : } \\
\text { banyak anak-anak di SDN Kecamatan Gubeng } \\
\text { menjawab sering melihat sinetron dan yang sering } \\
\text { dilihat adalah sinetron Anak Jalanan; pada ranah } \\
\text { afektif: anak-anak banyak yang suka terhadap } \\
\text { sinetron yang dilihatnya, dimana adegan yang } \\
\text { disukai adalah adegan berpacaran, sedangkan pada } \\
\text { ranah kognitif: anak-anak kadang-kadang } \\
\text { mempraktekkan adegan sinetron. Hal ini dapat } \\
\text { dipahami bahwa dalam menonton tayangan sinetron } \\
\text { tidak adanya pengawasan orang tua dan tidak } \\
\text { efektifnya pola komunikasi interpersonal dalam } \\
\text { keluarga sehingga anak bebas menonton dan bahkan } \\
\text { mempraktekkan apa yang ditayangkan pada sinetron } \\
\text { tersebut sehingga diperlukan pola komunikasi } \\
\text { interpersonal untuk pemberdayaan perilaku anak } \\
\text { sebagai perlindungan anak dalam menonton } \\
\text { tayangan sinetron di televisi }\end{array}$ \\
\hline 12 & $\begin{array}{l}\text { Journal of } \\
\text { Pediatric } \\
\text { Nursing } \\
\text { Mexican, } \\
\text { (Paloma et al., } \\
\text { 2017) }\end{array}$ & $\begin{array}{l}\text { Mexican } \\
\text { Adolescents' Self- } \\
\text { Reports of } \\
\text { Parental } \\
\text { Monitoring and } \\
\text { Sexual } \\
\text { Communication } \\
\text { for Prevention of } \\
\text { Sexual Risk } \\
\text { Behavior }\end{array}$ & \begin{tabular}{lr} 
Purpose: & Assess \\
perceptions & of \\
parental monitoring \\
and $r$ sexual \\
communication for \\
sexual health \\
promotion among \\
adolescents who are \\
\multicolumn{2}{l}{ Mexican. }
\end{tabular} & $\begin{array}{l}\text { Descriptive statistical } \\
\text { analyses were conducted } \\
\text { to assess } \\
\text { sociodemographic } \\
\text { characteristics of the } \\
\text { group. Chi-square } \\
\text { analyses were conducted } \\
\text { to identify potential } \\
\text { group differences among } \\
\text { the adolescents by age, } \\
\text { gender and sexual } \\
\text { activity regarding } \\
\text { responses to each item of } \\
\text { the Spanish Version } \\
\text { Parental Monitoring and } \\
\text { Sexual Communication } \\
\text { Scale }(\mathrm{a}=0.88) \text {. }\end{array}$ & $\begin{array}{l}\text { Sebelas persen remaja melaporkan aktivitas seksual } \\
\text { yang dilaporkan sendiri. Perbedaan kelompok yang } \\
\text { signifikan berdasarkan usia, jenis kelamin dan } \\
\text { aktivitas seksual diidentifikasi mengenai } \\
\text { pemantauan orang tua dan komunikasi seksual } \\
\text { termasuk: kurang pengawasan orang tua dengan usia } \\
\text { yang lebih tua (14 berbanding } 15 \text { tahun); lebih } \\
\text { banyak pengawasan orang tua untuk wanita daripada } \\
\text { pria; kurang pemantauan untuk remaja yang aktif } \\
\text { secara seksual; komunikasi seksual yang lebih besar } \\
\text { untuk pria daripada wanita. }\end{array}$ \\
\hline
\end{tabular}




\begin{tabular}{|c|c|c|c|c|c|}
\hline 13 & $\begin{array}{l}\text { Academic } \\
\text { Pediatrics, } \\
\text { (Gersh et al., } \\
\text { 2017) }\end{array}$ & $\begin{array}{l}\text { Adolescent } \\
\text { health-risk } \\
\text { behaviors: } \\
\text { Parental concern } \\
\text { and concordance } \\
\text { between parent } \\
\text { and adolescent } \\
\text { reports } \\
\text { Elon }\end{array}$ & $\begin{array}{l}\text { Investigated which } \\
\text { adolescent health- } \\
\text { risk behaviors are of } \\
\text { concern to parents } \\
\text { generally, according } \\
\text { to adolescent age, } \\
\text { gender, and in the } \\
\text { context of perceived } \\
\text { risk. Compared } \\
\text { adolescent and } \\
\text { parent reports of the } \\
\text { presence of health- } \\
\text { risk behaviors and } \\
\text { factors predicting } \\
\text { agreement }\end{array}$ & $\begin{array}{l}300 \text { adolescents aged } 13-18 \\
\text { (M=14.5, 52\% female) } \\
\text { presenting for well care } \\
\text { completed an electronic } \\
\text { screening tool assessing } \\
\text { health-risk behaviors. } \\
\text { Parents completed parallel } \\
\text { measures of their child's } \\
\text { behavior and parental } \\
\text { concern. Adolescent and } \\
\text { parent reports were } \\
\text { compared using McNemar's } \\
\text { test. Hierarchical linear } \\
\text { regression examined } \\
\text { predictors of agreement. }\end{array}$ & $\begin{array}{l}\text { Orang tua dalam mengasuh anak baik umumnya } \\
\text { memiliki kekhawatiran tentang perilaku gaya hidup } \\
\text { remaja. Sementara orang tua lebih cenderung } \\
\text { melaporkan kekhawatiran ketika mereka tahu, } \\
\text { tentang suatu perilaku, kekhawatiran orang tua tidak } \\
\text { selalu selaras dengan kesadaran orang tua akan } \\
\text { risiko, terutama untuk substansi. menggunakan. } \\
\text { laporan orang tua tentang prevalensi yang lebih } \\
\text { tinggi dari beberapa perilaku berisiko membantu } \\
\text { dalam identifikasi risiko yang kemungkinan terjadi. }\end{array}$ \\
\hline 14 & $\begin{array}{l}\text { Children and } \\
\text { Youth Services } \\
\text { Review, } \\
\text { (Pereyra \& } \\
\text { Bean, 2017) }\end{array}$ & $\begin{array}{l}\text { Latino adolescent } \\
\text { substance use: A } \\
\text { mediating model } \\
\text { of inter- parental } \\
\text { conflict, deviant } \\
\text { peer associations, } \\
\text { and parenting }\end{array}$ & 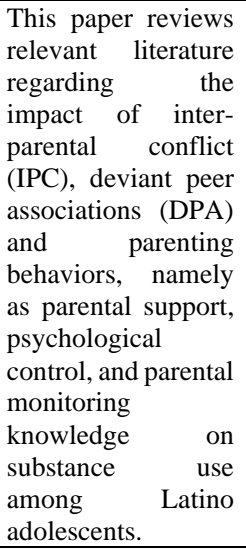 & $\begin{array}{l}\text { Structural equation } \\
\text { modeling was used to } \\
\text { analyze direct and } \\
\text { indirect relationships of } \\
\text { the variables mentioned } \\
\text { among } 744 \text { Latino } \\
\text { adolescents. Results }\end{array}$ & $\begin{array}{l}\text { Hasil menunjukkan bahwa DPA secara positif } \\
\text { terkait dengan penggunaan narkoba, pengetahuan } \\
\text { pemantauan orang tua berhubungan negatif dengan } \\
\text { penggunaan narkoba dan bahwa pengetahuan } \\
\text { pemantauan orangtua secara parsial memediasi } \\
\text { hubungan antara DPA dan penggunaan narkoba. }\end{array}$ \\
\hline 15 & $\begin{array}{l}\text { The European } \\
\text { Journal of } \\
\text { Psychology } \\
\text { Applied to } \\
\text { Legal } \\
\text { Context, } \\
\text { (Cutrín, }\end{array}$ & $\begin{array}{l}\text { Effects of } \\
\text { parenting } \\
\text { practices through } \\
\text { deviant peers on } \\
\text { nonviolent and } \\
\text { violent antisocial } \\
\text { behaviours in }\end{array}$ & $\begin{array}{l}\text { The aim of the } \\
\text { current study } \\
\text { was to analyse in } \\
\text { two age cohorts } \\
\text { the presence of } \\
\text { mediation }\end{array}$ & $\begin{array}{l}\text { The sample was } \\
\text { composed of } 584 \text { Spanish } \\
\text { young people from six } \\
\text { state high schools of } \\
\text { Galicia (NW Spain), } \\
46.9 \% \text { males }(\mathrm{n}=274), \\
\text { aged } 14 \text { to } 20(\mathrm{M}=15.99 \text {, } \\
\mathrm{SD}=1.20) \text {, and } 53.1 \%\end{array}$ & $\begin{array}{l}\text { Faktor keluarga menunjukkan pengaruh yang lebih } \\
\text { besar bagi remaja yang lebih muda, sedangkan } \\
\text { teman sebaya menunjukkan pengaruh yang lebih } \\
\text { besar pada remaja yang lebih tua. Temuan ini juga } \\
\text { menunjukkan pengaruh timbal balik dari proses } \\
\text { seleksi dan sosialisasi yang menyarankan perlunya } \\
\text { intervensi awal untuk mencegah perkembangan } \\
\text { perilaku antisosial. }\end{array}$ \\
\hline
\end{tabular}




\begin{tabular}{|c|c|c|c|c|c|}
\hline & $\begin{array}{l}\text { Gómez- } \\
\text { fraguela, } \\
\text { Maneiro, \& } \\
\text { Sobral, 2017) }\end{array}$ & $\begin{array}{l}\text { middle- and late- } \\
\text { adolescence }\end{array}$ & $\begin{array}{l}\text { effects of par- } \\
\text { enting practices }\end{array}$ & $\begin{array}{l}\text { females }(\mathrm{n}=310) \text {, aged } \\
14 \text { to } 19(\mathrm{M}=15.98, \mathrm{SD} \\
=1.17) \text {. The only } \\
\text { participant aged } 20 \text { was } \\
\text { removed from the final } \\
\text { study for comparison } \\
\text { purposes. }\end{array}$ & \\
\hline 16 & $\begin{array}{l}\text { Jurnal Psikologi } \\
\text { Integratif, } \\
\text { (Syifaunnufush, } \\
\text { Diana, Marsda, } \\
\text { Yogyakarta, \& } \\
\text { Fax, 2017) }\end{array}$ & $\begin{array}{l}\text { Kecenderungan } \\
\text { Kenakalan } \\
\text { Remaja Ditinjau } \\
\text { Dari Kekuatan } \\
\text { Karakter Dan } \\
\text { Persepsi } \\
\text { Komunikasi } \\
\text { Empatik Orangtua }\end{array}$ & $\begin{array}{l}\text { bertujuan untuk } \\
\text { mengetahui } \\
\text { hubungan antara } \\
\text { kekuatan karakter } \\
\text { dan persepsi } \\
\text { komunikasi empatik } \\
\text { orangtua dengan } \\
\text { kecenderungan } \\
\text { kenakalan remaja. }\end{array}$ & $\begin{array}{l}\text { Populasi penelitian ini } \\
\text { adalah siswa SMK Piri } 1 \\
\text { Yogyakarta dengan } \\
\text { sampel sebanyak 59 } \\
\text { siswa yang berusia antara } \\
15-18 \text { tahun. Teknik } \\
\text { pengambilan sampel } \\
\text { yang digunakan adalah } \\
\text { purposive sampling }\end{array}$ & $\begin{array}{l}\text { Hasil analisis menunjukkan koefisien korelasi }(\mathrm{R}) \\
\text { sebesar } 0,467 \text { dengan taraf signifikansi }(\mathrm{p}) \text { sebesar } \\
0,000(\mathrm{p}<0,05) \text {. Hal ini berarti terdapat hubungan } \\
\text { yang signifikan antara kekuatan karakter dan } \\
\text { persepsi komunikasi empatik orang tua dengan } \\
\text { kecenderungan kenakalan remaja. Sumbangan } \\
\text { efektif kekuatan karakter dan persepsi komunikasi } \\
\text { empatik sebesar } 21,8 \% \text { (R square }=0,218 \text { ). }\end{array}$ \\
\hline 17 & $\begin{array}{l}\text { Skripsi, (F. P. } \\
\text { Sari, 2017) }\end{array}$ & \begin{tabular}{l}
\multicolumn{2}{l}{ Pengaruh } \\
Intensitas \\
Komunikasi \\
Orang Tua Dan \\
Anak Terhadap \\
Sikap Sosial \\
Siswa Kelas Viii \\
Di Smp Negeri 4 \\
Terbanggi Besar \\
Oleh Febi \\
Purnama Sari \\
Tuju
\end{tabular} & $\begin{array}{l}\text { Tujuan penelitian } \\
\text { ini } \quad \text { untuk } \\
\text { menganalisis dan } \\
\text { mendeskripsikan } \\
\text { pengaruh intensitas } \\
\text { komunikasi orang } \\
\text { tua dan anak } \\
\text { terhadap sikap } \\
\text { sosial siswa kelas } \\
\text { VIII di SMP Negeri }\end{array}$ & $\begin{array}{lr}\text { Metode yang digunakan } \\
\text { penelitian } & \text { ini adalah } \\
\text { deskriptif } & \text { korelasional } \\
\text { dengan } & \text { pendekatan } \\
\text { kuantitatif } & \text { dengan } \\
\text { populasi } 228 & \text { responden } \\
\text { serta sampel } & \text { berjumlah } \\
34 \text { responden. }\end{array}$ & $\begin{array}{l}\text { Hasil penelitian ini menunjukan bahwa tidak } \\
\text { intensifnya komunikasi orang tua dan anak } \\
\text { mempengaruhi anak dalam menentukan sikap sosial } \\
\text { berupa jujur, disiplin, cinta damai dan santun, artinya } \\
\text { terdapat pengaruh intensitas komunikasi orang tua } \\
\text { dan anak terhadap sikap sosial siswa. }\end{array}$ \\
\hline 18 & $\begin{array}{l}\text { Academica, } \\
\text { (Setianingsih \& } \\
\text { Surakarta, 2017) }\end{array}$ & \begin{tabular}{lr}
\multicolumn{3}{l}{ Peran Komunikasi } \\
Ayah dalam \\
Perkembangan \\
Mental $r$ Anak: \\
Studi atas & Santri \\
Putri & Pondok \\
Tahfidz & \\
Karanganyar
\end{tabular} & $\begin{array}{l}\text { Mengeksplorasi } \\
\text { peran komunikasi } \\
\text { ayah dalam } \\
\text { perkembangan } \\
\text { mental anak }\end{array}$ & 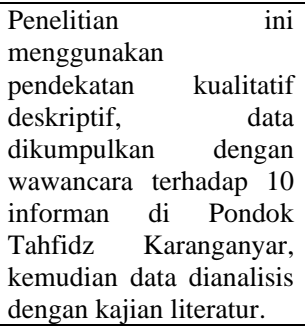 & $\begin{array}{l}\text { Kualitas komunikasi ayah dan anak dipengaruhi oleh } \\
\text { beberapa faktor, seperti tingkat pendidikan dan } \\
\text { kondisi ekonomi keluarga. Dengan demikian, ayah } \\
\text { harus memperhatikan kualitas komunikasinya agar } \\
\text { bisa menumbuhkan mental yang positif dalam diri } \\
\text { anak. }\end{array}$ \\
\hline 19 & $\begin{array}{lr}\text { Gadjah } & \text { Mada } \\
\text { Journal } & \text { Of } \\
\end{array}$ & $\begin{array}{l}\text { Persepsi terhadap } \\
\text { Kemampuan }\end{array}$ & $\begin{array}{l}\text { bertujuan untuk } \\
\text { mengetahui }\end{array}$ & $\begin{array}{l}\text { Metode analisis data } \\
\text { menggunakan teknik }\end{array}$ & $\begin{array}{l}\text { Hasil penelitian ini diperoleh } \mathrm{r}=-0,295(\mathrm{p}=0,001) \text {. } \\
\text { Hasil tersebut mendukung hubungan negatif antara }\end{array}$ \\
\hline
\end{tabular}




\begin{tabular}{|c|c|c|c|c|c|}
\hline & $\begin{array}{l}\text { Psychology } \\
\text { (Gamajop), } \\
\text { (Awanis \& } \\
\text { Adiyanti, } \\
\text { 2018) }\end{array}$ & \begin{tabular}{l|} 
Komunikasi \\
Interpersonal \\
Orang Tua dengan \\
Kecenderungan \\
Kenakalan \\
Remaja
\end{tabular} & $\begin{array}{l}\text { hubungan antara } \\
\text { persepsi terhadap } \\
\text { kemampuan } \\
\text { komunikasi } \\
\text { interpersonal orang } \\
\text { tua dengan } \\
\text { kecenderungan } \\
\text { kenakalan remaja. }\end{array}$ & $\begin{array}{l}\text { analisis korelasi Product } \\
\text { Moment Pearson. } \\
\text { Partisipan dalam } \\
\text { penelitian ini }(\mathrm{N}=100) \\
\text { merupakan individu usia } \\
\text { remaja tengah yang } \\
\text { berjenis kelamin laki-laki } \\
\text { dan perempuan, dan } \\
\text { menempuh pendidikan di } \\
\text { beberapa sekolah negeri } \\
\text { di Yogyakarta }\end{array}$ & $\begin{array}{l}\text { persepsi remaja terhadap kemampuan hubungan } \\
\text { interpersonal orang tua dengan kecenderungan } \\
\text { kenakalan remaja. }\end{array}$ \\
\hline 20 & $\begin{array}{l}\text { Computers in } \\
\text { Human } \\
\text { Behavior(Tech } \\
\text { noference, A, } \\
\text { Stockdale, } \\
\text { Coyne, \& } \\
\text { Padilla-walker, } \\
\text { 2018) }\end{array}$ & $\begin{array}{l}\text { Parent and Child } \\
\text { Technoference } \\
\text { and } \\
\text { Socioemotional } \\
\text { Behavioral } \\
\text { Outcomes: A } \\
\text { Nationally } \\
\text { Representative } \\
\text { Study of 10- to 20- } \\
\text { Year-Old } \\
\text { Adolescents }\end{array}$ & $\begin{array}{l}\text { The current study } \\
\text { examined the effect } \\
\text { of adolescents' } \\
\text { perceptions of their } \\
\text { own and their } \\
\text { parents } \\
\text { technoference on } \\
\text { adolescent positive } \\
\text { and negative } \\
\text { behaviors, including } \\
\text { anxiety, depression, } \\
\text { cyberbullying, } \\
\text { prosocial behavior, } \\
\text { and civic } \\
\text { engagement, as } \\
\text { mediated through } \\
\text { adolescent } \\
\text { perceptions of } \\
\text { parental warmth. }\end{array}$ & $\begin{array}{l}\text { Penelitian saat ini adalah } \\
\text { kuota sampel remaja } \\
\text { berusia } 10 \text { hingga } 20 \\
\text { tahun dari AS. Namun, } \\
\text { penelitian saat ini } \\
\text { menggunakan langkah- } \\
\text { langkah perilaku laporan } \\
\text { diri dan hanya mengukur } \\
\text { perilaku pada satu titik } \\
\text { waktu. }\end{array}$ & $\begin{array}{l}\text { Technoference remaja tidak terkait dengan persepsi } \\
\text { kehangatan orang tua, tetapi terkait dengan } \\
\text { meningkatnya cyberbullying, kecemasan, depresi, } \\
\text { dan penurunan perilaku prososial dan keterlibatan } \\
\text { masyarakat. Implikasi dari technoference dalam } \\
\text { konteks orang tua-remaja dibahas. }\end{array}$ \\
\hline 21 & $\begin{array}{l}\text { Asian Journal of } \\
\text { Psychiatry, } \\
\text { (Aboobaker, } \\
\text { Jangam, Sagar, } \\
\text { Amaresha, \& } \\
\text { Jose, 2018) }\end{array}$ & $\begin{array}{lr}\text { Predictors } & \text { of } \\
\text { emotional } & \text { and } \\
\text { behavioral } & \\
\text { problems among } \\
\text { Indian } \\
\text { adolescents: A } \\
\text { clinic-based study }\end{array}$ & $\begin{array}{l}\text { The current study } \\
\text { was designed to } \\
\text { determine the } \\
\text { predictors of } \\
\text { emotional and } \\
\text { behavioral } \\
\text { problems among } \\
\text { Indian adolescents }\end{array}$ & $\begin{array}{l}\text { The data were analyzed } \\
\text { with stepwise } \\
\text { linear and } \\
\text { regression }\end{array}$ & $\begin{array}{l}\text { Lingkungan psikososial yang tidak baik akan } \\
\text { mempengaruhi perilaku seseorang dalan menetukan } \\
\text { sikap dalam bertindak atau mengambil keputusan }\end{array}$ \\
\hline 22 & $\begin{array}{l}\text { Children and } \\
\text { Youth Services }\end{array}$ & $\begin{array}{l}\text { The effects of } \\
\text { parenting }\end{array}$ & $\begin{array}{l}\text { This study explores } \\
\text { the interplay }\end{array}$ & $\begin{array}{lll}\text { We } & \text { recruited } 1,988 \\
\text { adolescents (mean age }=\end{array}$ & $\begin{array}{l}\text { Temuan ini memberikan wawasan berharga tentang } \\
\text { sifat multidimensi perilaku pengasuhan dan }\end{array}$ \\
\hline
\end{tabular}

Commented [WU1]: Lihat kembali dengan sumber yang pasti 


\begin{tabular}{|c|c|c|c|c|c|}
\hline & $\begin{array}{l}\text { Review, (Ngai, } \\
\text { Xie, Ng, \& Ngai, } \\
\text { 2018) }\end{array}$ & $\begin{array}{l}\text { behavior } r \text { on } \\
\text { prosocial behavior } \\
\text { of Chinese } \\
\text { adolescents in } \\
\text { Hong Kong }\end{array}$ & $\begin{array}{lr}\text { between } & \text { parenting } \\
\text { behavior } & \text { and } \\
\text { prosocial } & \text { behavior } \\
\text { and } & \text { examines } \\
\text { whether } & \text { parenting } \\
\text { behavior } & \text { acts as a } \\
\text { mediator } & \text { that } \\
\text { explains } & \text { gender } \\
\text { differences } & \text { in } \\
\text { prosocial behavior }\end{array}$ & $\begin{array}{l}14.6 \text { years, } \mathrm{SD}=1.8) \\
\text { from } 17 \quad \text { secondary } \\
\text { schools in Hong Kong. }\end{array}$ & $\begin{array}{l}\text { prososial dan sebagian menjelaskan mekanisme } \\
\text { yang mendasari perbedaan gender dalam perilaku } \\
\text { prososial remaja. }\end{array}$ \\
\hline 23 & $\begin{array}{l}\text { Enfermeria } \\
\text { Clinica, } \\
\text { (Widyatuti, } \\
\text { Citra Hafilah } \\
\text { Sharina, 2018) }\end{array}$ & $\begin{array}{l}\text { Correlation } \\
\text { between parent- } \\
\text { adolescent } \\
\text { communication } \\
\text { and adolescents' } \\
\text { premarital sex risk }\end{array}$ & $\begin{array}{l}\text { Objective: Previous } \\
\text { studies have } \\
\text { indicated the parent- } \\
\text { adolescent } \\
\text { relationship has a } \\
\begin{array}{l}\text { correlation } \\
\text { adolescents' } \\
\text { premarital } \\
\text { behavior risk. }\end{array}\end{array}$ & 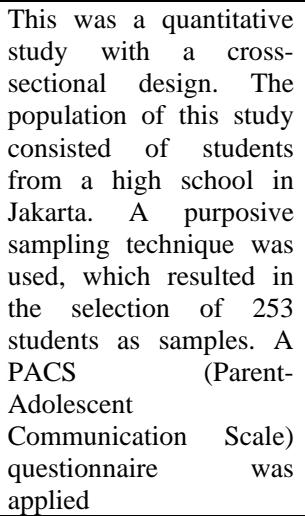 & $\begin{array}{l}\text { Komunikasi harus selaras dengan tugas } \\
\text { perkembangan remaja. Petugas atau kita juga dapat } \\
\text { membuat program promosi dengan topik } \\
\text { komunikasi untuk orang tua dan remaja }\end{array}$ \\
\hline 24 & $\begin{array}{l}\text { Children and } \\
\text { Youth Services } \\
\text { Review journal, } \\
\text { (Pereyra et al., } \\
\text { 2019) }\end{array}$ & $\begin{array}{lr}\begin{array}{l}\text { Longitudinal } \\
\text { study }\end{array} & \text { of } \\
\text { externalizing } & \\
\text { behaviors } & \text { in } \\
\text { Latino/a } & \\
\text { adolescents: } & \text { An } \\
\text { examination } & \text { of } \\
\text { parenting } & \text { and } \\
\text { educational } & \\
\text { factors } & \\
\end{array}$ & $\begin{array}{l}\text { Used to analyze } \\
\text { direct and indirect } \\
\text { effects of parenting } \\
\text { and academic } \\
\text { factors on } \\
\text { externalizing } \\
\text { behavior among } \\
\text { Latino/a adolescents } \\
\text { over time }\end{array}$ & $\begin{array}{lr}\text { Studi } & \text { Longitudinal } \\
\text { Nasional } & \text { Kesehatan } \\
\text { Remaja (Add Health) } \\
\text { using latent } & \text { growth } \\
\text { curves and } & \text { structural } \\
\text { equation } & \text { modeling } \\
\text { (SEM). } & \end{array}$ & $\begin{array}{l}\text { Hasil menunjukkan bahwa tingkat kehangatan ibu } \\
\text { yang lebih tinggi berpengaruh terhadap hubungan } \\
\text { remaja-guru, dan prestasi akademik remaja }\end{array}$ \\
\hline 24 & $\begin{array}{l}\text { Journal of } \\
\text { Applied } \\
\text { Developmenta }\end{array}$ & \begin{tabular}{ll|}
$\begin{array}{l}\text { Adolescents' } \\
\text { responses }\end{array}$ to \\
parental \\
regulation: & The \\
\end{tabular} & $\begin{array}{l}\text { This study } \\
\text { examined whether } \\
\text { adolescents' } \\
\text { perceptions } \quad \text { and } \\
\end{array}$ & $\begin{array}{l}\text { Remaja }(\mathrm{N}=294 ; \text { Mage }= \\
14,3) \quad \text { melaporkan } \\
\text { penentuan nasib sendiri } \\
\text { mereka, }\end{array}$ & $\begin{array}{l}\text { Gaya komunikasi orang tua dapat mendukung } \\
\text { otonomi atau mengendalikan psikologis. Setelah } \\
\text { skenario, remaja melaporkan persepsi mereka } \\
\text { tentang situasi (yaitu, kepuasan otonomi, frustrasi }\end{array}$ \\
\hline
\end{tabular}




\begin{tabular}{|c|c|c|c|c|c|}
\hline & $\begin{array}{l}\text { I Psychology. } \\
\text { (Petegem, } \\
\text { Zimmer- } \\
\text { gembeck, } \\
\text { Baudat, \& } \\
\text { Soenens, } \\
\text { 2019) }\end{array}$ & $\begin{array}{l}\text { role of } \\
\text { communication } \\
\text { style and self- } \\
\text { determination }\end{array}$ & \begin{tabular}{lr}
\multicolumn{2}{l}{ reactions to parental } \\
regulation & were \\
predicted & by \\
parents' & \\
communication & \\
style and & by \\
adolescents' self- \\
determination. \\
Adolescents
\end{tabular} & & $\begin{array}{l}\text { otonomi, legitimasi) dan tanggapan mereka yang } \\
\text { diantisipasi (yaitu, perlawanan oposisi, negosiasi). }\end{array}$ \\
\hline 25 & $\begin{array}{l}\text { Tesis, (Jannah, } \\
\text { 2019) }\end{array}$ & $\begin{array}{ll}\text { Peran Ibu } & \text { Dalam } \\
\text { Mengatasi } & \\
\text { Perilaku } & \\
\text { Menyimpang } \\
\text { Pada } & \text { Remaja } \\
\text { Keluarga } & \text { Broken } \\
\text { Home } & \end{array}$ & $\begin{array}{lr}\text { Penelitian } & \text { ini } \\
\text { bertujuan } & \text { untuk } \\
\text { mengetahui bentuk- } \\
\text { bentuk perilaku } \\
\text { menyimpang pada } \\
\text { remaja } & \text { keluarga } \\
\text { broken home dan } \\
\text { bagaimana peran } \\
\text { ibu } & \text { dalam } \\
\text { mengatasi perilaku } \\
\text { menyimpang pada } \\
\text { remaja keluarga } \\
\text { broken home. }\end{array}$ & $\begin{array}{l}\text { Metode penelitian ini } \\
\text { menggunakan penelitian } \\
\text { kualitatif }\end{array}$ & $\begin{array}{l}\text { Hasil penelitian ini menunjukan bahwa (1) Bentuk- } \\
\text { bentuk perilaku menyimpang remaja keluarga } \\
\text { broken home adalah : (a) penyimpangan individu: } \\
\text { berbohong, membolos, berlebihan dalam } \\
\text { berpacaran, meminjam uang tanpa sepengetahuan } \\
\text { orangtua. (2) peran ibu dalam mengatasi perilaku } \\
\text { menyimpang pada remaja keluarga broken home } \\
\text { dengan cara: berkomunikasi dengan baik, } \\
\text { menasehati, represif (menghambat), melakukan } \\
\text { pengawasan dengan baik }\end{array}$ \\
\hline 26 & $\begin{array}{l}\text { Skripsi, } \\
\text { (Bigupik, 2019) }\end{array}$ & $\begin{array}{l}\text { Peran Orang Tua } \\
\text { Dalam Mendidik } \\
\text { Kepribadian Anak } \\
\text { Di Desa Renah } \\
\text { Lebar Kecamatan } \\
\text { Karang Tinggi } \\
\text { Kabupaten } \\
\text { Bengkulu Tengah }\end{array}$ & $\begin{array}{l}\text { Penelitian ini } \\
\text { bertujuan untuk } \\
\text { mengetahui peran } \\
\text { orang tua dalam } \\
\text { mendidik } \\
\text { kepribadian anak di } \\
\text { desa Renah Lebar } \\
\text { Kecamatan Karang } \\
\text { Tinggi Kabupaten } \\
\text { Bengkulu Tengah. }\end{array}$ & $\begin{array}{l}\text { Metode yang digunakan } \\
\text { dalam penelitian ini } \\
\text { adalah metode kualitatif } \\
\text { denagn pendekatan } \\
\text { deskriptif }\end{array}$ & $\begin{array}{l}\text { Kondisi Kepribadian Anak di Desa Renah Lebar } \\
\text { Kecamatan Karang Tinggi Kabupaten Bengkulu } \\
\text { Tengah bahwa orang tua merupakan kepala } \\
\text { keluargga yang wajib dalam membimbing anak- } \\
\text { anaknya. Orang tua adalah ibu, bapa, lawan anak } \\
\text { kepala kaum keluarga. Tugas orang tua adalah } \\
\text { menjaga, merawat, memelihara mendidik anak: } \\
\text { membimbing Kepribadian adalah tingkah laku atau } \\
\text { akhlak seseorang dalam berperilaku, selanjutnya } \\
\text { keadaan kepribadian remaja di desa Renah Lebar } \\
\text { adalah baik, namun ada beberapa yang kurang baik, } \\
\text { dan perlu dibina dan diwasi oleh orangtua. }\end{array}$ \\
\hline
\end{tabular}




\section{Hasil dan Pembahasan}

Penulisan menelusuri pada artikel internasional bahwa komunikasi dalam keluarga positif sangat membantu mencengah perilaku menyimpangan pada remaja, dan keluarga yang haromis kecendrungan akan menghasilkan anak berperilaku positif dan mempunyai kepercayaan diri yang tinggi. Di sisi lain dari penelitian tersebut perilaku menyimpan seksual pranikah terjadi pada keluarga dengan pola kumunikasi permisif. Pengawasan oleh orang tua wanita lebih efektif maupun menurunkan angka kejadian penyimpangan perilaku pada remaja pria dan orang tua pria pada remaja wanita. kekhawatiran orang tua tidak selalu selaras dengan kesadaran orang tua akan risiko, kondisi tersebut dapat dilihat dan dibuktikan dengan penelitian yang dilakukan oleh. (Gersh et al., 2017). Orang tua juga harus memperhatikan anak remaja yang mempunyai riwayat penyakit kronis/pengunaan narkoba yang beresiko terjadinya perubahan perilaku menyimpang, dengan memberikan penyuluhan gaya hidup yang positif,(Vega-lópez et al., 2020). Gaya komunikasi orang tua akan mempengaruhi sikap positif anak dan remaja dalam berperilaku. Perlu menjadi catatan kita dalam mewaspadai remaja supaya tidak terjadi perilaku menyimpang adalah remaja harus selektif dalam memilih teman sebaya yang nanti bisa mempengaruhi remaja tersebut pada perilaku yang tidak baik. Penelusuran jurnal nasional telah terbukti bahwa komunikasi keluarga akan berdampak pada penympangan perilaku pada remaja dimana ditemukan pada artikel yang dibaca bahwa pengawasan orang tua sewaktu anak dan remaja menonton dirumah akan mempengaruhi mereka dalam berperilaku menyimpangan dan akan mempraktekkan dengan apa yang remaja lihatnya. Dengan komunikasi keluarga yang efektif dapat membantu penyelesaikan masalah yang muncul di dukung hasil penelitian menyatakan bahwa anak remaja di kelurahan Malalayang bertumbuh dalam keluarga yang harmonis, walaupun menurut mereka pertengkaran memang ada di antara anggota keluarga, namun bisa diatasi dan tidak menjadi halangan bagi pertumbuhan mereka sebagai remaja karena segala persoalan dalam rumah bisa mereka komunikasikan. (Tangkudung, 2014) Hasil penelitian ini menunjukan bahwa tidak intensifnya komunikasi orang tua dan anak mempengaruhi anak dalam menentukan sikap sosial berupa jujur, disiplin, cinta damai dan santun, artinya terdapat pengaruh intensitas komunikasi orang tua dan anak terhadap sikap sosial anak dan remaja.

Dalam keluarga komunikasi keluarga merupakan faktor penting dalam kehidupan anak (remaja). Komunikasi keluarga diduga dapat mempengaruhi, antara lain, prestasi belajar anak. Sesuai dengan menelitian yang dilakukan di Bandung hasil temuan sebagai berikut: (1) kredibilitas ayah dalam mengawasi belajar anak tidak mempengaruhi prestasi belajar anaknya. Ayah lebih penekanan peran untuk mencari nafkah. (2) kredibilitas ibu dalam mengawasi belajar anak dapat mendukung prestasi belajar anak dalam pelajarannya di sekolah; (3) frekuensi komunikasi yang dilakukan ayah mempengaruhi prestasi belajar yang diraih anak; (4) frekuensi komunikasi ibu dengan anak yang tinggi tidak menentukan prestasi belajar anak menjadi tinggi. (Kurniadi, 2001)

\section{Simpulan}

Pola komunikasi dalam keluarga atau peran keluarga sangat berpengaruh dalam mencengah supaya anak tidak berperilaku 
yang menyimpang terutama dalam seksualis pra nikah, dan menumbuhkan kedisiplin percaya diri, cepat mampu beradaptasi dengan lingkungan yang baru, peran guru disekolah menjadi pigur yang memberikan contoh dan tauladan dalam memberikan pendidikan di sekolah. Lingkungan teman sebaya anak dan remaja harus lebih selektif dalam menentukan atau bergaul sehingga tidak terpengaruh pada perilaku yang negative yang merugikan diri sendiri.

\section{E. Ucapan Terima Kasih}

Terima kasih kepada pihak Sekolah Tinggi Islam Bukitinggi dan Universitas Fort De Kock yang sudah memfasilitasi.

\section{REFERENCE}

Aboobaker, S., Jangam, K. V, Sagar, K. J. V., Amaresha, A. C., \& Jose, A. (2018). Predictors of emotional and behavioral problems among Indian adolescents: A clinic-based study. Asian Journal of Psychiatry. https://doi.org/10.1016/j.ajp.2018.12.00 2

Awanis, F., \& Adiyanti, M. G. (2018). Persepsi terhadap Kemampuan Komunikasi Interpersonal Orang Tua dengan Kecenderungan Kenakalan Remaja. GADJAH MADA JOURNAL OF PSYCHOLOGY (GAMAJOP), 4(2), 135-142. https://doi.org/10.22146/gamajop.4636 0

Berdibayeva, S., Garber, A., \& Ivanov, D. (2016). Psychological prevention of older adolescents ' interpersonal relationships, who are prone to internet addiction. Social and Behavioral Sciences, 217, 984-989. https://doi.org/10.1016/j.sbspro.2016.0 2.081
Bigupik, I. Z. A. (2019). PERAN ORANG TUA DALAM MENDIDIK KEPRIBADIAN ANAK DI DESA RENAH LEBAR KECAMATAN KARANG TINGGI KABUPATEN BENGKULU TENGAH. Institut Agama Islam Negeri Bengkulu.

Cutrín, O., Gómez-fraguela, J. A., Maneiro, L., \& Sobral, J. (2017). The European Journal of Psychology Applied to Legal Context and violent antisocial behaviours in middle- and lateadolescence. The European Journal of Psychology Applied to Legal Context, 9(2), 75-82.

https://doi.org/10.1016/j.ejpal.2017.02. 001

Farin Nur, P. L., \& Program. (2020). PERUBAHAN PERILAKU KELUARGA DALAM PEMENUHAN TUGAS PERKEMBANGAN REMAJA MELALUI PENINGKATAN PENGETAHUAN KELUARGA DI DESA GODO KECAMATAN WINONG KABUPATEN PATI. Healthy Tadulako Journal, 6(1), 41-48.

Firdanianty, D. P. L., \& Herien Puspitawati, D. S. (2016). K omunikas I. KOmunikasi, 01, 37-47.

Ford, C. A., D, M., Cheek, C., Culhane, J., Ph, D., H, M. P., ... Ph, D. (2016). Parent and Adolescent Interest in Receiving Adolescent Health Communication Information From Primary Care Clinicians. Journal of Adolescent Health. https://doi.org/10.1016/j.jadohealth.201 6.03 .001

Gersh, E., Richardson, L. P., Katzman, K., Spielvogle, H., Zhou, C., \& Mccarty, C. A. (2017). Adolescent health-risk behaviors: Parental concern and concordance between parent and 
adolescent reports. Academic

Pediatrics.

https://doi.org/10.1016/j.acap.2017.08. 012

\section{ILMU KOMUNIKASI DAN ISLAM.}

(2008). TEORI TENTANG KOMUNIKASI KELUARGA DAN PERILAKU KEAGAMAAN REMAJA.

Jannah, H. N. (2019). PERAN IBU DALAM MENGATASI PERILAKU MENYIMPANG PADA REMAJA KELUARGA BROKEN HOME. Institut Agama Islam Negeri Purwokerto.

KEMENTERIAN, \& INDONESIA, P. P. D. P. A. R. (2019). Panduan pencegahan dan penanganan anak perilaku sosial menyimpang.

Komunikasi, M., \& Keluarga, D. (2015). Jurnal Edueksos Volume IV No 1, Januari - Juni 2015 1. Edueksos, IV(1), $1-19$.

Kurniadi, O. (2001). Pengaruh Komunikasi Keluarga terhadap Prestasi belajar Anak. Mediator, 2(2), 267-290.

Ngai, S. S., Xie, L., Ng, Y., \& Ngai, H. (2018). The effects of parenting behavior on prosocial behavior of Chinese adolescents in Hong Kong. Children and Youth Services Review, (2017), \#pagerange\#. https://doi.org/10.1016/j.childyouth.201 8.02.030

Novi Kartika Sari, W. S. H. (2016). NHUBUNGAN ANTARA DUKUNGAN KELUARGA DENGAN KECENDERUNGAN PERILAKU DELINKUEN PADA REMAJAo Title. Tesis. Muhammadiyah Surakarta.

Nurlita, I. (2016). INTERPERSONAL COMMUNICATIONS PATTERN FOR CHILDREN' S BEHAVIOR EMPOWERMENT AGAINST
SINETRON ( SOAP OPERA ). Cakrawala, 10(2), 155-168.

Paloma, S., Dávila, E., Dimmitt, J., Guadalupe, M., Monsiváis, M., Tovar, M., ... Arias, F. (2017). Journal of Pediatric Nursing Mexican Adolescents ' Self-Reports of Parental Monitoring and Sexual Communication for Prevention of Sexual Risk Behavior. Journal of Pediatric Nursing, 35, 8389. https://doi.org/10.1016/j.pedn.2017.03. 007

Pereyra, S. B., \& Bean, R. A. (2017). PT CR. Children and Youth Services Review, (2016), 2-44. https://doi.org/10.1016/j.childyouth.201 7.03.001

Pereyra, S. B., Bean, R. A., Yorgason, J. B., Lee, C., Sandberg, J. G., \& Miller, R. B. (2019). Children and Youth Services Review Longitudinal study of externalizing behaviors in Latino / a adolescents : An examination of parenting and educational factors. Children and Youth Services Review Journal, 107(September), 104513. https://doi.org/10.1016/j.childyouth.201 9.104513

Petegem, S. Van, Zimmer-gembeck, M., Baudat, S., \& Soenens, B. (2019). Journal of Applied Developmental Psychology Adolescents ' responses to parental regulation: The role of communication style and selfdetermination. Journal of Applied Developmental Psychology, 65(August 2018), 101073. https://doi.org/10.1016/j.appdev.2019.1 01073

Petra, U. K., Devi, L., Komunikasi, P. I., Kristen, U., \& Surabaya, P. (2015). Proses Komunikasi Interpersonal Ibu Yang Bekerja Dalam Pembentukkan 
Sikap Konatif Anak. Journal E

Komunukasi, 3(1), 2-10.

Press, A. I. N. (2006). The relationships of adolescent school-related deviant behaviour and victimization with psychological distress : Testing a general model of the mediational role of parents and teachers across groups of gender and age. Adolescence, 29, 671690.

https://doi.org/10.1016/j.adolescence. 2 005.08.015

Rogers, A. A., S, M., Ha, T., Ph, D., Stormshak, E. A., Ph, D., ... Ph, D. (2015). Quality of Parent e Adolescent Conversations About Sex and Adolescent Sexual Behavior: An Observational Study. Journal of Adolescent Health, 57(2), 174-178. https://doi.org/10.1016/j.jadohealth.201 5.04 .010

Sari, A., Hubeis, A. V. S., Mangkuprawira, S., \& Saleh, A. (2010). Pengaruh Pola Komunikasi Keluarga dalam Fungsi Sosialisasi Keluarga terhadap Perkembangan Anak. JUrnal Komunikasi Pembangunan, 08(2).

Sari, F. P. (2017). No TitlePENGARUH INTENSITAS KOMUNIKASI ORANG TUA DAN ANAK TERHADAP SIKAP SOSIAL SISWA KELAS VIII DI SMP NEGERI 4 TERBANGGI BESAR. Lampung.

Schouten, B. C., Putte, B. Van Den, Pasmans, M., \& Meeuwesen, L. (2007). Parent - adolescent communication about sexuality: The role of adolescents ' beliefs, subjective norm and perceived behavioral control. Patient Education and Counseling, 66, 75-83.

https://doi.org/10.1016/j.pec.2006.10.0 10
Setianingsih, F., \& Surakarta, I. (2017).

Peran Komunikasi Ayah dalam Perkembangan Mental Anak : Studi atas Santri Putri Pondok Tahfidz Karanganyar. Academica, 1(2), 170184.

Sondakh, W. A. M., \& Kalesaran, E. R. (2017). PERAN KOMUNIKASI KELUARGA DALAM MENGATASI PERILAKU MEROKOK PADA ANAK USIA REMAJA. Acta Diurna, VI(1), 1-14.

Suhartati, V., Hendrati, F., Psikologi, F., \& Malang, U. M. (2015). PERBEDAAN KOMUNIKASI INTERPERSONAL ANAK- ORANGTUA DITINJAU DARI KEHARMONISAN PERKAWINAN ORANG TUA. Jurnal Psikologi Tabularasa, 10(2), 145-153.

Syifaunnufush, A. D., Diana, R. R., Marsda, J., Yogyakarta, A., \& Fax, T. (2017). Kecenderungan Kenakalan Remaja Ditinjau Dari Kekuatan Karakter Dan Persepsi Komunikasi Empatik Orangtua. Psikologi Integratif, 5(1), 47-68.

Tangkudung, J. (2014). PERANAN KOMUNIKASI KELUARGA DALAM MENCEGAH KENAKALAN REMAJA DI KELURAHAN MALALAYANG I KECAMATAN MALALAYANG OLEH. Tesis, III(1).

Technoference, C., A, S. B. O., Stockdale, L. A., Coyne, S. M., \& Padilla-walker, L. M. (2018). Parent and Child Technoference and Socioemotional Behavioral Outcomes: A Nationally Representative Study of 10- to 20Year-Old Adolescents. Computers in Human Behavior. https://doi.org/10.1016/j.chb.2018.06.0 34 
Vega-lópez, S., Marsiglia, F. F., Ayers, S., Rankin, L., Bruening, M., Gonzalvez, A., ... Hartmann, L. (2020). Methods and rationale to assess the e ffi cacy of a parenting intervention targeting diet improvement and substance use prevention among Latinx adolescents. Contemporary Clinical Trials, 89(July 2019), 105914.

https://doi.org/10.1016/j.cct.2019.1059 14

Widyatuti, Citra Hafilah Sharina, A. Y. N.

(2018). Correlation between parentadolescent communication and adolescents' premarital sex risk. Enfermeria Clinica, 28(1), 51-54.
https://doi.org/10.1016/S1130-

8621(18)30036-6

Yuniartanty Ashary, Tawany Rahamma, J.

M. F. (2015). PENGENDALIAN

PERILAKU EMOSIONAL ANAK TK

MELALUI KOMUNIKASI ANTARA

GURU DENGAN ORANG TUA DI

KEC. BIRINGKANAYA KOTA

MAKASSAR. Komunikasi KAREBA, 4(4), 415-434.

Zuhri, S. (2015). POLA KOMUNIKASI ORANG TUA DENGAN ANAK PADA KASUS SEKS PRANIKAH. Ilmu KOmunikasi, 7(2), 59-70. 